Saudi Journal of Oral and Dental Research

Abbreviated Key Title: Saudi J Oral Dent Res

ISSN 2518-1300 (Print) |ISSN 2518-1297 (Online)

Scholars Middle East Publishers, Dubai, United Arab Emirates

Journal homepage: https://saudijournals.com

\title{
Systematic Review of the Online Data Available for Educational Applications in Prosthodontics
}

Saleem Ali Qasem Atiah", Aisha Mohammed Saleh Yamani, Abdulhamid Aidarous Alamir, Maan Mohammed A Shabi, Hassan Ibrahim Ahmed Khormi, Dr. Fatima Sultana

Jazan University, College of Dentistry, Saudi Arabia

DOI: 10.36348/sjodr.2020.v05i12.010

| Received: 28.11 .2020 | Accepted: 24.12.2020 | Published: 30.12 .2020

*Corresponding author: Saleem Ali Qasem Atiah

\section{Abstract}

Background: Prosthodontics is the branch of dentistry that deals with the replacement of missing teeth and other orofacial structures with artificial substitute. In prosthodontics, implants, removable and fixed dentures can be used to replace missing teeth. Digital dentistry is the new trend that is evolving globally among the dental professionals and the dental students. Interactive learning concepts and objective evaluation in this digital Technologies with 24/7 access to the dental undergraduates and post graduates in providing education and training about prosthodontics is highly valuable. Aim: The aim of this study is to do the systematic review of the online Data available for educational applications for Prosthodontics. Materials and Methods: In order to conduct a systematic review of the online data available for educational applications in prosthodontics, the rules and guidelines of preferred reporting items of systematic reviews and meta-analysis (PRISMA) were followed. Results: Of the total 453 articles only about 11 articles ware included in the systematic review that reported the online data available for educational applications in prosthodontics. Conclusion: The dental education of prosthodontics can be revolutionized, using the online available data to create educational applications.

Keywords: Prosthodontics, prosthodontist, digitalization, education applications, online data, virtual learning, digital dentistry.

Copyright $\odot 2020$ The Author(s): This is an open-access article distributed under the terms of the Creative Commons Attribution 4.0 International License (CC BY-NC 4.0) which permits unrestricted use, distribution, and reproduction in any medium for non-commercial use provided the original author and source are credited.

\section{INTRODUCTION}

In Present time, information and Communication Technology is a crucial element of learning and teaching in case of Healthcare professionals. The aspect of clinical practice by the Healthcare professionals has been transformed by implementing educational applications of mobile devices. For Communication, information management and clinical decision various applications have been created in the mobile devices that are made common for Healthcare settings. In order to manage patient's record, clinical trial discussion, preparation of post graduate examination various kinds of apps are available in the field of dentistry. The dental graduates and dental professionals of the present generation are positive about using numerous mobile apps for practice.

The branch of dentistry that deals with the replacement of missing teeth and other orofacial structures with artificial substitute is called as prosthodontics. Implants, removable and fixed dentures can be used to replace missing teeth in the patient. This artificial substitutes are mostly made up of metals, ceramics, heat cure acrylic and cold cure acrylic. Digital dentistry is the new trend that is evolving globally among the dental professionals and the dental students [1].

Many of the Western countries have been using well-equipped Software Solutions to manage patient's record, to make an appointment, recall reminders, ordering materials, managing the maintenance contract of the medical devices, checking the working time schedule. Digital dentistry can assists to provide knowledge and information about maintaining the medical history of the patient and also perform digital radiography, take intra-oral photographs and also provides the medicine list. The restorations can be fabricated in the laboratory in order to plan the oral rehabilitation by using the intra-oral optical scanning (IOS) [2]. The three-dimensional radiography for guided implant placement can be done using the the digital dentistry. 
In most of the dental laboratories the IOS scanner is used especially in the European countries. The 3D model files that are given by the clinician using the IOS is used by the dental technician to facilitate the fabrication of restorations. The digital design created has various advantages in case of quality control, information about the material thickness And also the cross section values of connector when compared to waxing. The Prosthodontic product that are manufactured in the industries using additive printing process with subtractive meaning can be improvised. The dental wax castings have shortcomings leading to various errors and shrinkage cavities [3].

In order to enhance the clinical correlation, Spatial ability, Critical thinking, Interactivity of the students a number of 3D educational programs have been launched. This 3D education programs are integrated with multiple dental disciplines. 3D visualisation gives Augmented reality (AR) to the tooth morphology that helps in the treatment of removable or fixed partial dentures. Due to the identical set-ups the transparency for all the students is to be enhanced using digital Technologies that include 3D printing of virtual teeth.

Educational motor skills, training and clinical testing is increased using the application of virtual reality (VR) and the Augmented reality (AR) using the maxillofacial surgical protocols. Interactive learning concepts and objective evaluation in this digital Technologies with 24/7 access to the dental undergraduates and post graduates in providing education and training about prosthodontics is highly valuable. In recent times the simulation of hardware, realism of simulation, scoring system and validation is to be done using the virtual reality applications especially in case of preclinical Prosthodontic education. There is a high need for the use of virtual reality application in the Prosthodontic education. In order to understand the benefits and limitations of the conventional and digital processes a proper training need to be provided to the dental professionals, medical doctors, insurance providers, dental students and Dental technicians [4]. This digital training helps the Prosthodontic students manage to digitalise data and also ensure the safety of the patient.

Various Advanced Dental education programs in the Prosthodontic specialisation is to be provided in order to educate the graduate dental students to give better delivery of prosthodontic care. The dental student should be trained to perform the wide range of clinical procedures in the speciality of prosthodontics at the level of proficiency. Prosthodontic faculty need to recognise and select experienced and highly competent prosthodontics that helps to accomplish the management of patients, prosthetic needs successfully by giving comfortable, satisfied, acceptable and efficient prosthodontic treatment on time. Dental education programs in prosthodontics can help and educate the graduate dental students to perform research in prosthodontics efficiently. The prosthodontic dental teaching can encourage the dental students virtually grow using the digital platform. The digital training skills includes the IOS with digital surface mapping, 3D printing and prototyping. In order to improve their education and training of the dental graduates in prosthodontics, digital applications can be used [5].

The Saudi Commission for health specialities (SCFHS) updates the information related to prosthodontics available online. It provides curriculum development in the field of Medical and Dental education related to the literature on prosthodontics and is made available online for the dental students of Saudi Arabia. The literature that is related to the prosthodontic residents, observation of test performed by the prosthodontics, critical incidents related to prosthodontics and study of role model (prosthodontist). To create educational application for prosthodontics, the information related to diagnosis, treatment, rehabilitation and maintenance of the oral cavity should be available. There is a lack of evidence of systematic review of the online data that is made available for the educational applications in prosthodontics and hence this topic was selected.

\section{AIM AND OBJECTIVES}

The aim of this study is to do the systematic review of the online Data available for educational applications for Prosthodontics.

\section{FILTERS USED}

Human studies, studies in English language, adults of 18 years and old.

\section{TIME LINE OF STUDY}

A total of 6 months time was taken collect the data, analyze it, write the manuscript and proposal, and review the manuscript and proposal.

\section{METHODOLOGY}

The rules and guidelines of preferred reporting items of systematic reviews and meta-analysis (PRISMA) were followed in order to conduct a systematic review of the present topic. The systematic review was carried out in English language. The systematic review was done by an electronic search using PUBMED, Medline, Scopus, and Embase. All the articles that follow the inclusion criteria were selected for the systematic review of literature related to the online data available for educational applications in prosthodontics. After the selection of the articles they were searched manually by the principal investigator. All the information extracted from the online web search was entered in a pre designed Data extraction form. The outcome of the research is clearly observed and the results are recorded. The descriptive studies, 
case-control studies, cohort studies, randomised controlled trials and observational trials were investigated to systematically review the literature that is made available for the educational application. The articles that were incomplete and not didn't provide complete information about the study design are excluded from this research. The reviewers of this research individually studied and reviewed the title, abstract and full text related to each article based on the inclusion criteria. Mutual conflicts or disagreement regarding the research was resolved by carrying out a discussion.

\section{RESULTS}

Identified about 453 titles that were related to the educational data on prosthodontics. After screening 216 articles were selected. The articles in only English language was selected. About 158 articles were selected after eliminating the studies with only abstracts. Using the filters about 34 articles were selected for reviewing by the principal investigator. Upon manual reviewing by the reviewers only about 11 articles ware included in the systematic review that reported the online data available for educational applications in prosthodontics.

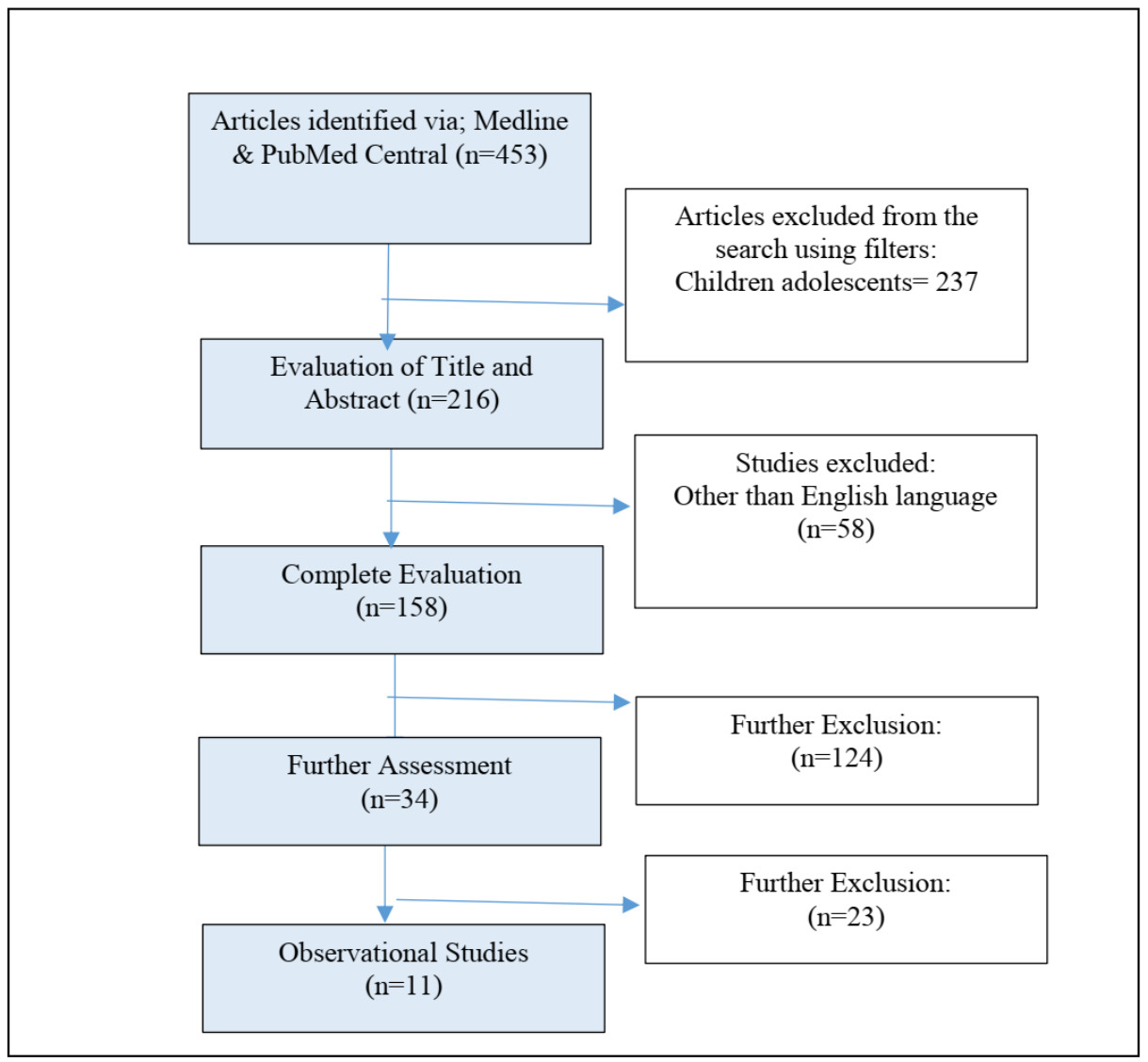

Natural ageing, innate disease, or accident causes the loss of natural teeth and oral structures which can be a traumatizing incident in a patient's life. Due to the loss of natural teeth a person can lose his ability to chew his food and smile. This can lead to Embarrassment and the person avoid public gatherings. In order to enhance the quality of life of such person, prosthodontics plays an important role in restoring the the missing teeth and other oral structures.

The branch of dentistry that focuses on designing, developing and fitting of artificial restoration for the missing teeth is called as prosthodontics. By following proper diagnosis, treatment plan, rehabilitation and maintenance Dentists can restore oral function and facial appearance of the patient. The dentist that is specialised to restore the teeth by using artificial restoration it's called as a prosthodontist. After completion of graduation from a dental School the dentist need to take advanced training in prosthodontics to become a prosthodontist. The prosthodontist need to be efficiently trained in various aspects like dental implants, crown, temporomandibular disorder, bridges and aesthetics. Sometimes Prosthodontist are referred to as 'Architects of the smile'.

Prosthetic restorations need to be carried out for the following reasons: Replacing missing teeth, dental implantation, cosmetic dentistry, removable or fixed partial dentures, snoring disorders, traumatic injuries of oral cavity and Jaws, geriatric patients, temporomandibular joint disorder, babies born with cleft palates, and oral cancer reconstruction. 
Saleem Ali Qasem Atiah et al; Saudi J Oral Dent Res, Dec, 2020; 5(12): 609-615

\begin{tabular}{|c|c|c|c|c|c|}
\hline $\begin{array}{l}\text { AUTHOR'S } \\
\text { NAME }\end{array}$ & $\begin{array}{l}\text { YEAR } \\
\text { OF } \\
\text { STUDY }\end{array}$ & $\begin{array}{l}\text { STUDY } \\
\text { CONDUCTED } \\
\text { ON }\end{array}$ & SOURCE & DISCUSSION & RESULTS \\
\hline $\begin{array}{l}\text { G N Graser et } \\
\text { al., [6] }\end{array}$ & 1990 & $\begin{array}{l}\text { Removable } \\
\text { prosthodontic } \\
\text { education }\end{array}$ & $\begin{array}{l}\text { J Prosthet } \\
\text { Dent }\end{array}$ & $\begin{array}{l}\text { The practitioner's interest } \\
\text { in removable } \\
\text { prosthodontics as it } \\
\text { relates to new techniques } \\
\text { and materials remains } \\
\text { high according to a } 1988 \\
\text { survey of Academy of } \\
\text { General Dentistry } \\
\text { members. }\end{array}$ & $\begin{array}{l}\text { Removable prosthodontics } \\
\text { was rated first in regards } \\
\text { to continuing education } \\
\text { courses desired by its } \\
\text { members. }\end{array}$ \\
\hline $\begin{array}{l}\text { G P Mc } \\
\text { Givney et al., } \\
{[7]}\end{array}$ & 1990 & $\begin{array}{l}\text { Advanced } \\
\text { education in } \\
\text { prosthodontics }\end{array}$ & $\begin{array}{l}\text { J Prosthet } \\
\text { Dent }\end{array}$ & $\begin{array}{l}\text { Accredited advanced } \\
\text { education programs in } \\
\text { prosthodontics are } \\
\text { currently meeting the } \\
\text { standard guidelines for } \\
\text { clinical and didactic } \\
\text { experiences }\end{array}$ & $\begin{array}{l}\text { TMJ therapy and geriatric } \\
\text { dentistry need to be better } \\
\text { defined in the educational } \\
\text { guidelines. }\end{array}$ \\
\hline $\begin{array}{l}\text { Douglas V } \\
\text { Chaytor et } \\
\text { al., [8] }\end{array}$ & 2005 & $\begin{array}{l}\text { Changes in } \\
\text { prosthodontics } \\
\text { education, past } \\
\text { and future }\end{array}$ & $\begin{array}{l}\text { J Can Dent } \\
\text { Assoc }\end{array}$ & $\begin{array}{l}\text { Organizational support } \\
\text { for defining the } \\
\text { speciality of } \\
\text { prosthodontics to } \\
\text { encompass a broad } \\
\text { spectrum of dental } \\
\text { restorations and related } \\
\text { care helped develop } \\
\text { commitment to improved } \\
\text { research and education. }\end{array}$ & $\begin{array}{l}\text { Prosthodontic education } \\
\text { will continue to evolve, } \\
\text { but it will be influenced by } \\
\text { its institutional and } \\
\text { professional } \\
\text { environments. }\end{array}$ \\
\hline $\begin{array}{l}\text { Gunnar E } \\
\text { Carlsson et } \\
\text { al., [9] }\end{array}$ & 2006 & $\begin{array}{l}\text { Trends in } \\
\text { prosthodontics }\end{array}$ & $\begin{array}{l}\text { Med Princ } \\
\text { Pract }\end{array}$ & $\begin{array}{l}\text { Another factor } \\
\text { increasingly influencing } \\
\text { prosthodontic practice is } \\
\text { patients' awareness of } \\
\text { newer technologies in } \\
\text { aesthetic dentistry. }\end{array}$ & $\begin{array}{l}\text { It describes the recent } \\
\text { developments in } \\
\text { prosthodontics and its } \\
\text { therapeutic areas, and the } \\
\text { impact such developments } \\
\text { may have on the theory } \\
\text { and practice of the } \\
\text { discipline. }\end{array}$ \\
\hline $\begin{array}{l}\text { Saee } \\
\text { Dshpande et } \\
\text { al., [10] }\end{array}$ & 2017 & $\begin{array}{l}\text { Mobile learning } \\
\text { app }\end{array}$ & $\begin{array}{l}\text { Educ Health } \\
\text { (Abingdon) }\end{array}$ & $\begin{array}{l}\text { A greater confidence in } \\
\text { their clinical decision } \\
\text { making around } \\
\text { prostheses through this } \\
\text { app and } 94 \% \text { of the } \\
\text { students felt that this app } \\
\text { should be regularly used } \\
\text { along with conventional } \\
\text { teaching techniques. }\end{array}$ & $\begin{array}{l}\text { Clinical decision-making } \\
\text { in prosthodontics, a } \\
\text { mobile learning app, is an } \\
\text { effective way to improve } \\
\text { clinical reasoning skills } \\
\text { for planning prosthodontic } \\
\text { rehabilitation. }\end{array}$ \\
\hline $\begin{array}{l}\text { Stephen D } \\
\text { Campbell et } \\
\text { al., [11] }\end{array}$ & 2017 & $\begin{array}{l}\text { Removable } \\
\text { partial denture }\end{array}$ & $\begin{array}{l}\text { J Prosthet } \\
\text { Dent }\end{array}$ & $\begin{array}{l}\text { The data on treatment for } \\
\text { partial edentulism were } \\
\text { reviewed and } \\
\text { summarized with a focus } \\
\text { on currently available } \\
\text { and future RPD designs, } \\
\text { materials, means of } \\
\text { production, and impact } \\
\text { on oral health. }\end{array}$ & $\begin{array}{l}\text { Advances in materials and } \\
\text { digital design/production } \\
\text { along with patient } \\
\text { education promise to } \\
\text { further the application of } \\
\text { RPDs and improve the } \\
\text { quality of life for patients } \\
\text { requiring RPDs. }\end{array}$ \\
\hline
\end{tabular}




\begin{tabular}{|c|c|c|c|c|c|}
\hline $\begin{array}{l}\text { Trevor D } \\
\text { Crafts et al., } \\
{[12]}\end{array}$ & 2017 & $\begin{array}{l}\text { Three } \\
\text { Dimensional } \\
\text { Printing }\end{array}$ & $\begin{array}{l}\text { Otolaryngol } \\
\text { Head Neck } \\
\text { Surg }\end{array}$ & $\begin{array}{l}\text { Emerging technologies } \\
\text { include the printing of } \\
\text { tissue scaffolds for the } \\
\text { auricle and nose, more } \\
\text { realistic training models, } \\
\text { and personalized } \\
\text { implantable medical } \\
\text { devices. }\end{array}$ & $\begin{array}{l}\text { Educational and training } \\
\text { models provide an } \\
\text { opportunity to better } \\
\text { visualize anomalies, } \\
\text { practice surgical } \\
\text { technique, predict } \\
\text { problems that might arise, } \\
\text { and improve quality by } \\
\text { reducing mistakes. }\end{array}$ \\
\hline $\begin{array}{l}\text { D Kalpana et } \\
\text { al., [13] }\end{array}$ & 2018 & $\begin{array}{l}\text { Digital Dental } \\
\text { Photography }\end{array}$ & $\begin{array}{l}\text { Indian J } \\
\text { Dent Res }\end{array}$ & $\begin{array}{l}\text { Application in dental } \\
\text { practice is simple, fast, } \\
\text { and extremely useful in } \\
\text { documenting procedures } \\
\text { of work, education of } \\
\text { patients, and pursuing } \\
\text { clinical investigations, } \\
\text { thus providing many } \\
\text { benefits to the dentists } \\
\text { and patients. }\end{array}$ & $\begin{array}{l}\text { Digital dental photography } \\
\text { over film photography, } \\
\text { basic armamentarium for } \\
\text { obtaining good } \\
\text { photographs, and how } \\
\text { digital dental photography } \\
\text { is beneficial in the field of } \\
\text { prosthodontics. }\end{array}$ \\
\hline $\begin{array}{l}\text { Charles J } \\
\text { Goodacre et } \\
\text { al., [14] }\end{array}$ & 2018 & $\begin{array}{l}\text { Digital learning } \\
\text { resources in } \\
\text { prosthodontics }\end{array}$ & $\begin{array}{l}\mathrm{J} \\
\text { Prosthodont }\end{array}$ & $\begin{array}{l}\text { These key factors can be } \\
\text { incorporated into student } \\
\text { learning through the use } \\
\text { of 3D education } \\
\text { programs in class. } \\
\text { Lessons learned from } \\
\text { using these programs } \\
\text { include the importance of } \\
\text { regular use in class as } \\
\text { well as testing students } \\
\text { both visually and } \\
\text { textually }\end{array}$ & $\begin{array}{l}\text { The students miss an } \\
\text { opportunity to enhance } \\
\text { their ability to visualize } \\
\text { structures three } \\
\text { dimensionally and } \\
\text { manipulate them in their } \\
\text { minds, a process known as } \\
\text { spatial ability that is } \\
\text { linked to success in the } \\
\text { sciences. }\end{array}$ \\
\hline $\begin{array}{l}\text { E Alexakou } \\
\text { et al., [15] }\end{array}$ & 2019 & $\begin{array}{l}\text { Clinical } \\
\text { applications in } \\
\text { prosthodontics }\end{array}$ & $\begin{array}{l}\text { Eur J } \\
\text { Prosthodont } \\
\text { Restor Dent }\end{array}$ & $\begin{array}{l}\text { Polyether ether ketone } \\
\text { (PEEK) is a polymer } \\
\text { with many potential } \\
\text { applications in dentistry. }\end{array}$ & $\begin{array}{l}\text { The current trend is } \\
\text { moving towards the use of } \\
\text { metal-free restorations and } \\
\text { biomaterials which exhibit } \\
\text { advanced properties in the } \\
\text { complex oral } \\
\text { environment. The } \\
\text { educational data related to } \\
\text { this can enhance the } \\
\text { Dental teaching. }\end{array}$ \\
\hline $\begin{array}{l}\text { Ahmed } \\
\text { Mahrous et } \\
\text { al., [16] }\end{array}$ & 2019 & $\begin{array}{l}\text { Latest } \\
\text { advancements in } \\
\text { virtual 3D } \\
\text { Modelling }\end{array}$ & $\begin{array}{l}\mathrm{J} \\
\text { Prosthodont }\end{array}$ & $\begin{array}{l}\text { the use of 3D modelling } \\
\text { software has enabled the } \\
\text { creation of 3D models } \\
\text { that can be altered or } \\
\text { customized to be used in } \\
\text { a more flexible way to } \\
\text { teach students in the arts } \\
\text { and complexities of } \\
\text { removable partial denture } \\
\text { (RPD) design and } \\
\text { associated components. }\end{array}$ & $\begin{array}{l}\text { It demonstrates using } \\
\text { videos and web-based } \\
\text { portals to show how the } \\
\text { 3D RPD models were } \\
\text { created and then used for } \\
\text { educational purposes. }\end{array}$ \\
\hline
\end{tabular}

Knowledge about simulator training in the preparation of cavity is to be made available for the undergraduate dental students especially in case of surgical interventions. Due to availability of virtual reality computer-assisted data, the instruction time of teaching from the faculty can be minimised. The data online for education applications in prosthodontics can access improvised interaction in the virtual oral environment. The virtual oral environment can explore the mandible, maxilla, tongue, enamel, dentine, cementum and pulp of the oral cavity. Knowledge about Computer aided design (CAD) and Computer aided manufacturing (CAM) can help in enhancing the student's with crown digitalization and framework 
design. The use of online data for the education applications in prosthodontics can help the inexperienced dental students to acquire skills needed for using digital tools. However the training given can be time-consuming when compared to the conventional techniques.

Detailed Knowledge about 3D Rapid prototyping can help in training the graduate dental students about the specialised techniques and skills. The graduate dental students prefer the digital Technologies in learning about prosthodontics when come to the conventional method of teaching. The use of textbooks for gaining knowledge and training in prosthodontics have decreased due to extensive use of educational applications.

Various studies reported that the student's Diagnostic skills are enhanced by using the digital educational applications in prosthodontics with the data that is available online. The Computer aided learning programs helps in increasing the accuracy of radiographic detection of caries. Many of the dental students have positive attitude and learning in prosthodontics for the development of educational applications using the data available online.

However with this study we do not intend to replace communicative interactions between prosthodontic faculty and dental students with the educational applications. This study Aims to just enhance the learning and training program in prosthodontics for better productivity using the digital applications.

\section{DISCUSSION}

The present study aimed to systematically review the literature that is available online in the field of prosthodontics. The online data can help in creating educational digital applications that can enhance the quality of education. A descriptive approach systematic review of prosthodontic literature was done. In the present time, especially in case of pandemic situations the digitalization in the dental education is required. The content related to prosthodontics that is made online need to be authentic. The educational applications also help in increasing the communication between the students and teachers, thus facilitating their learning ability via digitalization [16]. Training and instruction need to be provided for E-learning and Eteaching to both dental students and dental faculty respectively [17]. With the availability of the online data in prosthodontics a student can get easy assistance in all 24 hours of the day [18]. Due to covid-19 pandemic that was initially identified in the year 2019, many dental schools were closed as a precautionary step [19]. If the dental education is not digitalised using the web based learning platforms, no interactive learning can be made between the student and the dental faculty [20]. The educational applications in prosthodontics can include the videos and other interactive tools to ease learning [21]. Information related to prosthodontics that is made available online need to be properly assessed by the dental faculty to avoid misleading [22]. The interactive digital educational applications can make the student learn to self access their work with self reflection and get proper guidance from the faculty [2325].

Inspite of the Global digitalization of dental teaching, the data available related to the prosthodontics is not up to mark. Proper information about the diagnosis, treatment plan, rehabilitation and maintenance of prosthodontics is unavailable online. More research need to be carried out to determine the accuracy of the available prosthodontic data online. The protocols and guidelines need to be maintained by the educational applications to provide correct and authentic knowledge to the dental graduates about prosthodontics. Digitalization and transformation about the dental education is trending all across the world.

\section{CONCLUSION}

Simulation related to e-learning and eteaching, need to be added in the dental curriculum, to enhance the use of digital tools and educational applications for dental education. The guidelines need to be established in case of digital standards of prosthodontics education. The dental education of prosthodontics can be revolutionized, using the online available data to create educational applications. The content from various text books of prosthodontics should be made available online for easy access to the student. The conventional system of learning followed the use of text book knowledge for the students that was not easy, but with digitalization the information is much easy to access.

\section{REFERENCES}

1. Qing, H. (2017). Prosthodontic specialty training in the United States: what can we learn. Zhonghua kou qiang yi xue za zhi= Zhonghua kouqiang yixue zazhi $=$ Chinese journal of stomatology, 52(12), 718-722.

2. Al- Sowygh, Z. H., \& Sukotjo, C. (2011). Foreign- trained dentists in advanced education in prosthodontics programs in the United States: demographics, perspectives on current training, and future goals. Journal of Prosthodontics: Implant, Esthetic and Reconstructive Dentistry, 20(2), 161-165.

3. Montero, J., Dib, A., Guadilla, Y., Flores, J., Santos, J. A., Aguilar, R. A., \& Gómez-Polo, C. (2018). Dental Students' Perceived Clinical Competence in Prosthodontics: Comparison of Traditional and Problem- Based Learning Methodologies. Journal of dental education, 82(2), 152-162. 
4. Dhima, M., Petropoulos, V. C., Salinas, T. J., \& Wright, R. F. (2013). Predoctoral dental students' perceptions and experiences with prosthodontics. Journal of Prosthodontics: Implant, Esthetic and Reconstructive Dentistry, 22(2), 148-156.

5. Sadid- Zadeh, R., Sannito, N. M., \& DeLuca, J. T. (2019). Comparison of effectiveness of two teaching methods on acquisition of skills in preclinical fixed prosthodontics. Journal of dental education, 83(3), 314-321.

6. Graser, G. N. (1990). Review of the literature: Predoctoral removable prosthodontics education. The Journal of prosthetic dentistry, 64(3), 326-333.

7. McGivney, G. P. (1990). Review of the literature: Advanced education in prosthodontics. Journal of Prosthetic Dentistry, 64(3), 334-341.

8. Chaytor, D. V. (2005). Prosthodontics 1966-2042: changes in prosthodontic education, past and future. J Can Dent Assoc, 71(5), 329.

9. Carlsson, G. E., \& Omar, R. (2006). Trends in prosthodontics. Medical Principles and Practice, 15(3), 167-179.

10. Deshpande, S., Chahande, J., \& Rathi, A. (2017). Mobile learning app: A novel method to teach clinical decision making in prosthodontics. Education for Health, 30(1), 3134.

11. Campbell, S. D., Cooper, L., Craddock, H., Hyde, T. P., Nattress, B., Pavitt, S. H., \& Seymour, D. W. (2017). Removable partial dentures: The clinical need for innovation. The Journal of prosthetic dentistry, 118(3), 273-280.

12. Crafts, T. D., Ellsperman, S. E., Wannemuehler, T. J., Bellicchi, T. D., Shipchandler, T. Z., \& Mantravadi, A. V. (2017). Three-dimensional printing and its applications in otorhinolaryngology-head and neck surgery. Otolaryngology-Head and Neck Surgery, 156(6), 999-1010.

13. Kalpana, D., Rao, S. J., Joseph, J. K., \& Kurapati, S. K. R. (2018). Digital dental photography. Indian Journal of Dental Research, 29(4), 507-512.

14. Godderidge, J. G., Wall, B. E., \& Franklin, S. A. (2019). Creating an efficient learning model: students' perceptions and outcomes of an active learning fixed prosthodontics course. Journal of Dental Education, 83(9), 1076-1080.

15. Alexakou, E., Damanaki, M., Zoidis, P., Bakiri, E., Mouzis, N., Smidt, G., \& Kourtis, S. (2019). PEEK High Performance Polymers: A Review of Properties and Clinical Applications in Prosthodontics and Restorative Dentistry. The
European journal of prosthodontics and restorative dentistry, 27(3), 113-121.

16. Mahrous, A., \& Schneider, G. B. (2019). Enhancing student learning of removable prosthodontics using the latest advancements in virtual 3D modeling. Journal of Prosthodontics, 28(4), 471-472.

17. Wright, R. F., Dunlop, R. A., Kim, F. M., Weber, H. P., \& Donoff, R. B. (2008). A survey of deans: trends, challenges, and mentoring in prosthodontics. Part 2. Journal of Prosthodontics, 17(2), 149-155.

18. Sukotjo, C., Thammasitboon, K., Howell, H., \& Karimbux, N. (2008). Students' perceptions of prosthodontics in a PBL hybrid curriculum. Journal of Prosthodontics, 17(6), 495501.

19. Mattheos, N., Albrektsson, T., Buser, D., De Bruyn, H., Donos, N., Hjørting Hansen, E., ... \& Nattestad, A. (2009). Teaching and assessment of implant dentistry in undergraduate and postgraduate education: a European consensus. European Journal of Dental Education, 13, 10-17.

20. Park, S. E., \& Howell, T. H. (2015). Implementation of a patient- centered approach to clinical dental education: a five- year reflection. Journal of Dental Education, 79(5), 523-529.

21. Schwindling, F. S., Deisenhofer, U. K., Porsche, M., Rammelsberg, P., Kappel, S., \& Stober, T. (2015). Establishing CAD/CAM in preclinical dental education: evaluation of a hands- on module. Journal of dental education, 79(10), 12151221.

22. Fernandez, M. A., Nimmo, A., \& BeharHorenstein, L. S. (2016). Digital denture fabrication in pre- and postdoctoral education: a survey of US dental schools. Journal of Prosthodontics, 25(1), 83-90.

23. Mattheos, N., Ivanovski, S., Heitz- Mayfield, L., Klineberg, I., Sambrook, P., \& Scholz, S. (2010). University teaching of implant dentistry: guidelines for education of dental undergraduate students and general dental practitioners. An Australian consensus document\#. Australian dental journal, 55(3), 329-332.

24. Klokkevold, P. R. (2001). Implant education in the dental curriculum. Journal of the California Dental Association, 29(11), 747-755.

25. Puryer, J., Woods, K., Terry, J., Sandy, J., \& Ireland, A. J. (2018). The confidence of undergraduate dental students when carrying out prosthodontic treatment and their perception of the quality of prosthodontic education. European Journal of Dental Education, 22(1), e142-e148. 